\title{
Consumer preferences for theme based home furnishings
}

\author{
ANITA RUHIL, NIRMAL YADAV AND NISHA ARYA
}

Received: 27.01.2017; Revised: 23.04.2017; Accepted: 10.05.2017

See end of the paper for authors' affiliations ANITA RUHIL

Department of Textile and Apparel Designing, I.C. College of Home Science, C.C.S. Haryana Agricultural University, HISAR (HARYANA) INDIA

Email : anitahau05@gmail.com
ABSTRACT : The present study was conducted in Hisar and Gurgaon city to assess the consumer's preferences about theme based designing for home furnishings. Fifty consumers from each city (Hisar and Gurgaon) were selected purposively, which constituted a total sample of hundred consumers. The consumers were the ultimate users of home furnishings. The data revealed that majority of the respondents $(81.00 \%)$ were not awared or had no idea about theme based home furnishings but they decorate the area of home according with the matching interiors $(63.00 \%)$. Consumers $\left(2.59 \overline{\mathrm{X}}_{\mathrm{w}}\right)$ preferred the area for theme based home furnishings were drawing cum lounge area followed by lounge area and drawing room because family members generally relax, socialize in this area and use it for leisure and informal entertainment. Ten theme based design line were created for home furnishings by using different designing software's in $2 \mathrm{D}$ and $3 \mathrm{D}$ rendering in virtual design drawing cum lounge area

KEY WORDS: Consumer, Home furnishings, Preferences, Theme, Design

- HOW TO CITE THIS PAPER : Ruhil, Anita, Yadav, Nirmal and Arya, Nisha (2017). Consumer preferences for theme based home furnishings. Asian J. Home Sci., 12 (1) : 201-204, DOI: 10.15740/HAS/ AJHS/12.1/201-204. 